\title{
Implementasi literasi budaya dan kewargaan sebagai solusi disinformasi pada generasi millennial di Indonesia
}

\author{
Anggi Pratiwi', Eflinnida Nurul Komaril Asyarotin ${ }^{2}$ \\ 12Program Studi Ilmu Perpustakaan, Universitas Negeri Malang \\ Jl. Semarang No.5, Lowokwaru, Malang, Jawa Timur, Indonesia 65145 \\ E-mail: ${ }^{1}$ anggipratiwi246@gmail.com, 2eflinnida08@gmail.com
}

Received: January 2019; Accepted: June 2019; Published: June 2019

\begin{abstract}
The emergence of disinformation phenomena that occur currently in the millennial generation is due to the easygoing attitude that believes in the information obtained without looking at the truth or examining the credibility of the information source. Eventually, the millennial generation does not have the analytical thinking process of using information. The purpose of this study was to get a picture of disinformation that occurred in the millennial generation and explained the application of cultural literacy and citizenship as a solution to overcome disinformation. The research used the literature study method with a qualitative approach. Data collection used primary and secondary data obtained through various kinds of literature in the last ten years (2009-2019) such as books, e-books, e-journals, and proceedings. Based on the results of the analysis of the problems studied and supported by the theory used, the results showed that cultural and citizenship education could be applied in millennial generation literacy styles. This generation could be more selective in receiving and processing information obtained, could prevent the emergence of hoaxes and hate speech circulating in the community and instill cultural values and citizenship in the lifestyle in the millennial era. The steps taken are activity programs that contain useful information processing process that shapes an individual to become more selective in processing information obtained as well as implementing cultural literacy and citizenship independently in schools, family, and environment.
\end{abstract}

Keywords: Disinformation; Cultural and citizenship literacy; Millennials

\begin{abstract}
Abstrak
Munculnya fenomena disinformasi yang terjadi saat ini pada generasi millennial disebabkan sikap mudah percaya pada informasi yang diperoleh tanpa melihat kebenarannya atau mencari dulu dari mana sumbernya. Akhirnya generasi millennial tidak memiliki kemampuan menganalisis dalam menggunakan informasi. Tujuan penelitian ini adalah untuk mendapatkan gambaran disinformasi yang terjadi pada generasi millennial dan menjelaskan penerapan dari literasi budaya dan kewargaan sebagai solusi dalam mengatasi disinformasi. Metode penelitian yang digunakan yaitu metode studi literatur dengan pendekatan kualitatif. Jenis data yang digunakan ialah data primer dan sekunder yang diperoleh melalui berbagai literatur dalam 10 tahun terakhir (2009-2019) yaitu berupa buku, e-book, e-journal, dan prosiding. Berdasarkan hasil analisis yang dilakukan terhadap permasalahan yang dikaji dan didukung dengan berbagai teori yang digunakan, diperoleh hasil bahwa pendidikan budaya dan kewargaan yang diterapkan dalam gaya literasi generasi millennial bisa lebih selektif dalam menerima dan mengolah informasi yang diperoleh. Maka untuk mencegah kemunculan hoax dan hate speeech yang beredar di masyarakat, generasi millennial harus menanamkan nilai budaya dan kewargaan dalam gaya hidup. Langkah yang diambil ialah dengan program kegiatan yang berisi mengenai proses pengolahan informasi yang baik dan membentuk seseorang agar bisa menjadi generasi yang lebih selektif dalam mengolah informasi yang diperoleh serta penerapan literasi budaya dan kewargaan secara mandiri yaitu di ranah sekolah, keluarga dan lingkungan.
\end{abstract}

Kata Kunci: Disinformasi; Literasi budaya dan kewargaan; Generasi millennial 


\section{PENDAHULUAN}

Perkembangan teknologi informasi di era millennial membuat masyarakat bisa mengakses informasi secara mudah dan cepat tanpa batasan waktu. Generasi yang terlahir di era millennial menganggap teknologi sebagai kebutuhan primer. Mereka tidak bisa lepas dari teknologi informasi dan komunikasi. Prensky (2001) dalam Istiana (2016) mengatakan bahwa, "Digital native adalah mereka yang terbiasa dengan struktur kognitif yang melompatlompat, mampu melakukan beberapa kegiatan dalam waktu yang bersamaan." Perkembangan teknologi ke arah maya atau Internet of Things (IoT) membuka pintu arus informasi dan komunikasi secara global, lewat berbagai media internasional mudah sekali diakses informasi dari luar secara instan. Secara cepat masyarakat terseret arus globalisasi di segala bidang, pertukaran budaya merupakan salah satu hal yang mudah diambil masyarakat.

Lyons (2004) dalam Putra (2016) berpendapat kalau,

“Generasi millennial atau generasi $\mathrm{Y}$ merupakan ungkapan yang mulai dipakai pada editorial koran besar Amerika Serikat pada Agustus 1993. Generasi ini banyak menggunakan teknologi komunikasi yang instan seperti email, SMS, instant messaging dan media sosial seperti Facebook, dan Twitter, dengan kata lain generasi millennial adalah generasi yang tumbuh pada era internet booming."

Setiap individu (generasi millennial) memiliki karakteristik berbeda, yaitu tergantung latar belakang tempat tinggal, strata ekonomi, sosial keluarga, dan pola komunikasi yang sangat terbuka dibandingkan generasi sebelumnya. Selain itu, generasi millennial lebih terbuka dalam pandangan politik dan ekonomi karena mereka pengguna media sosial yang fanatik dan terpengaruh perkembangan teknologi informasi dan komunikasi. Mereka terlihat sangat reaktif terhadap perubahan lingkungan yang terjadi di sekelilingnya.

Perkembangan teknologi juga mengakibatkan kemunculan fenomena negatif yaitu permasalahan disinformasi. Disinformasi merupakan dampak pendistribusian fake news yang beredar secara online di dunia maya. Masyarakat mudah sekali menyerap informasi secara umum karena penyebaran disinformasi sangat cepat dan mudah diterima. Walaupun permasalahan disinformasi terselesaikan, fenomena ini mungkin masih terus membentuk kesan ke dalam perilaku sosial masyarakat. Oleh karena itu, penting bagi masyarakat untuk bisa membedakan jenis informasi yang dapat menyebabkan disinformasi serta menelusuri alasan dari penciptaan dan pendistribusiannya.

Disinformasi adalah penyampaian informasi yang salah, baik yang dilakukan dengan sengaja untuk membingungkan orang lain. Disinformasi yang terjadi pada masyarakat disebabkan karena masyarakat mudah percaya dengan informasi yang diperoleh tanpa melihat atau mencari lagi dari mana sumber informasi aslinya. Disinformasi yang terjadi di masyarakat harus bisa diatasi dengan baik, agar masyarakat terutama pada generasi millennial bisa lebih cerdas lagi, baik dalam menggunakan maupun mengomunikasikan informasi yang diperoleh di abad 21 ini.

Untuk mengatasi fenomena disinformasi diperlukan kemampuan literasi. Literasi tidak hanya sekadar 
kemampuan membaca dan menulis, tetapi literasi bisa berarti melek teknologi, politik, berpikir kritis, dan peka terhadap lingkungan sekitar (Irianto \& Febrianti, 2017). Pentingnya kesadaran literasi sangat mendukung keberhasilan seseorang dalam menangani berbagai permasalahan. Seseorang apabila memiliki kemampuan literasi akan memperoleh ilmu pengetahuan dan mendokumentasikan sepenggal pengalaman yang akan menjadi rujukan di masa mendatang.

Kementrian Pendidikan dan Kebudayaan (2017) menyatakan bahwa, "Kemampuan literasi budaya dan kewargaan adalah keterampilan perilaku dalam kebudayaan nasional sebagai identitas bangsa serta memahami hak dan kewajiban sebagai warga negara." Literasi budaya dan kewargaan merupakan kemampuan seseorang dalam bersikap sebagai bagian dari suatu budaya dan bangsa dalam lingkungan sosialnya. Pemerintah memanfaatkan pendidikan literasi sebagai media penanaman nilai nasionalisme dan patriotisme pada masyarakat di era millennial melalui program Gerakan Literasi Nasional di Indonesia.

Literasi budaya merupakan,

"Kemampuan dalam memahami dan bersikap terhadap kebudayaan Indonesia sebagai identitas bangsa, sementara literasi kewargaan adalah kemampuan dalam memahami hak dan kewajiban sebagai warga negara. Dengan demikian, literasi budaya dan kewargaan merupakan kemampuan individu dan masyarakat dalam bersikap terhadap lingkungan sosialnya sebagai bagian dari suatu budaya dan bangsa" (Kementrian

Pendidikan dan Kebudayaan, 2017).

Literasi budaya dan kewargaan menjadi hal yang penting untuk dikuasai di abad ke-21 oleh setiap orang terutama generasi millennial, agar mereka dapat tetap mencintai dan ikut melestarikan kebudayaan Indonesia. Negara ini memiliki beragam suku bangsa, bahasa, kebiasaan, adat istiadat, kepercayaan, dan lapisan sosial. Negara Indonesia sebagai bagian dari dunia, turut terlibat dalam kancah perkembangan dan perubahan global. Oleh karena itu, kemampuan untuk menerima dan beradaptasi, serta bersikap secara bijaksana dan cerdas atas keberagaman tersebut menjadi sesuatu yang penting untuk dilakukan di abad 21 ini.

Kemampuan untuk memahami keberagaman dan tanggung jawab sebagai warga negara dari suatu bangsa merupakan kecakapan yang harus dimiliki setiap individu di abad ke-21. Oleh karena itu, literasi budaya dan kewargaan penting diberikan di tingkat keluarga, sekolah, dan masyarakat pada masyarakat terutama generasi millennial, agar tetap mencintai dan bisa melestarikan kebudayaan di Indonesia baik secara nasional maupun internasional. Literasi budaya dan kewargaan tidak hanya menyelamatkan dan mengembangkan budaya lokal dan nasional, tetapi juga membangun identitas bangsa Indonesia di tengah masyarakat global, agar tetap mencintai dan bisa melestarikan kebudayaan tersebut.

Kewarganegaraan atau bangsa di Indonesia terbentuk atas beragam suku, bahasa, adat istiadat, kepercayaan, dan lapisan sosial. Indonesia pun merupakan salah satu negara anggota dari benua Asia, lebih luasnya menjadi bagian dari dunia yang pasti membuatnya turut serta dalam 
perubahan serta perkembangan dan perubahan internasional. Oleh karena itu, kemampuan untuk menerima dan beradaptasi, mampu bersikap secara bijaksana di tengah sapuan perubahan skala global merupakan hal yang mutlak.

$$
\text { Literasi selalu dimaksudkan }
$$
sebagai kemampuan dasar dalam hal membaca, menghitung, dan menulis. Literasi mulai diperkenalkan sejak dini pada anak untuk membentuk sikap yang baik. Namun seiring perkembangannya konsep literasi berubah menjadi rangkaian keterampilan dalam berbagai macam kelompok dilihat dari perspektif berbagai bidang seperti munculnya literasi informasi, literasi kesehatan, literasi teknologi, literasi ekonomi, literasi budaya dan lain-lain. Literasi tidak lagi hanya dipandang sebagai kemampuan dasar atau alat yang mendukung proses pembelajaran akademik tetapi sudah menjadi faktor pendukung kebutuhan masyarakat akan akses informasi yang akurat dan terpercaya, kemampuan berpikir seorang individu dalam menyelesaikan permasalahan, serta etika sikap sosial dalam berinteraksi antar kelompok dalam masyarakat.

Saat ini di setiap negara, dukungan terhadap keterampilan literasi semakin besar di antaranya kebebasan pers media digital, meningkatnya jumlah perpustakaan berkualitas, ketersediaan teknologi informasi dan komunikasi guna memudahkan seseorang dalam mengakses informasi, dan kewajiban mengintegrasikan dalam kurikulum pendidikan yang dilindungi undangundang. Seorang individu membutuhkan keterampilan literasi untuk bisa beradaptasi dengan lingkungan, menyelesaikan sejumlah isu melalui kemampuan literasi seperti pemerataan pendidikan, kondisi kesehatan, kesejahteraan ekonomi, dan lingkungan politik budaya.

Artikel ini mengkaji tentang implementasi literasi budaya dan kewargaan sebagai solusi disinformasi pada generasi millennial, yaitu seperti apa kebutuhan informasi generasi millennial, pemahaman terhadap hate speech yang disebabkan fenomena disinformasi serta bagaimana literasi budaya dan kewargaan dapat bermanfaat bagi generasi millennial. Kehidupan generasi millennial tidak bisa lepas dari pengunaan teknologi yang membantu dalam penelusuran sebuah informasi secara mudah dan cepat. Hal tersebut menyebabkan munculnya fenomena disinformasi yang terjadi saat ini pada generasi millennial disebabkan sikap mudah percaya pada informasi yang diperoleh tanpa melihat kebenarannya atau mencari dulu dari mana sumbernya. Permasalahan tersebut membuat penelitian studi literatur ini penting dilakukan.

Ada beberapa penelitian yang dapat dihubungkan mengenai perkembangan disinformasi. Pertama, penelitian Ahmad (2013), mengenai beberapa media online yang memunculkan situs Islam yang telah digunakan sebagai media jihad oleh para aktivis Islam di seluruh dunia termasuk Indonesia. Beberapa media online terindikasi menyebarkan berita bohong (hoax) mengenai ajaran Islam. Maka, umat Islam dianjurkan harus menganalisis informasi ini lebih lanjut.

Kedua, penelitian Henriette and Windiani (2018) yang diambil dari program pengabdian kepada masyarakat di 5 SMA di Kota Semarang, di antaranya SMA Islam Hidayatullah, SMA Muhammadiyah 1, SMA Bina Bangsa, 
SMAN 4 Semarang, dan SMAN 5 Semarang. Penyuluhan ini praktik literasi informasi menggunakan modul pembelajaran UNSECO 2018, yang berisi materi, “(1) Pemahaman Hoaks sebagai penyimpangan informasi, baik itu Misinformasi, Dis-informsi maupun Malinformasi; (2) Melawan Disinformasi dan Misinformasi melalui LMI; serta (3) ExPost Fact Checking / Memeriksa Fakta setelah Dipublikasikan" (Henriette \& Windiani, 2018). Berdasarkan penyuluhan ini, siswa/siswi di 5 SMA di Semarang dapat menganalisis informasi dengan cermat karena mereka sebagai pengguna aktif media sosial.

Sesuai rujukan kedua penelitian ini, masyarakat khususnya generasi millennial merupakan pengguna aktif media sosial dan konten informasi lainnya. Generasi millennial harus belajar menganalisis informasi yang mereka terima agar tidak menerima informasi yang salah. Dengan demikian, bila dihubungkan dengan penelitian ini, maka diharapkan generasi millennial dapat menambah wawasan intelektual pustakawan maupun guru di ruang lingkup sekolah yang ingin memahami lebih jauh dalam penerapan literasi budaya dan kewargaan secara kependidikan dan problematika disinformasi pada generasi millennial. Selain itu, artikel ini dibuat sebagai pertimbangan mengenai pentingnya permasalahan budaya baik daerah maupun nasionalisme pada generasi millennial yang mudah tersulut provokasi dari fenomena disinformasi. Adapun manfaat lainnya ialah melalui artikel ini dapat memberikan pemahaman mengenai literasi budaya dan kewargaan bagi masyarakat luas terutama generasi millennial. Generasi ini memerlukan kemampuan literasi untuk mempertahankan identitas dan nilai bangsa dalam arus perkembangan zaman yang semakin bebas.

\section{METODE PENELITIAN}

Penelitian ini menggunakan metode studi literatur melalui pendekatan kualitatif, yang bertujuan untuk memaparkan permasalahan yang dikaji dan memberikan solusi untuk mengatasi masalah tersebut secara terperinci dan mendalam sesuai dengan hasil analisis dan teori yang digunakan. Jenis data yang digunakan melalui sumber data primer dan sekunder, diperoleh melalui berbagai literatur dalam 10 tahun terakhir (20092019). Literatur berjumlah 18 literatur yaitu berupa buku, e-book, e-journal, prosiding dan sebagainya. Teknik pengumpulan data dilakukan dengan analisis terhadap berbagai literatur yang berhubungan dengan topik permasalahan yang dikaji.

Metode penelitian kualitatif merupakan suatu pendekatan deskriptif dalam memahami fenomena yang terjadi pada lingkungan sosial dengan memberikan gambaran yang jelas dari fakta yang ditemukan di lapangan. Tujuan dari penelitian studi literatur melalui pendekatan kualitatif ialah menjelaskan fenomena disinformasi yang terjadi di kehidupan masyarakat terutama generasi millennial sehingga dapat teratasi melalui penerapan literasi budaya dan kebudayaan pada ranah keluarga, masyarakat dan sekolah. Rahmat (2009) dalam Novianto (2017) menjelaskan bahwa, penelitian kualitatif disebut juga sebagai, "Penelitian natural karena data pada penelitian ini bersifat alami atau natural, peneliti sebagai alat penelitian yang artinya peneliti sebagai alat utama pengumpulan data." Data penelitian 
bersumber dari tinjauan literatur lalu dianalisis oleh peneliti.

\section{HASIL DAN PEMBAHASAN}

Ketika era millennial, teknologi selalu digunakan untuk mendukung berbagai rutinitas pengisi waktu luang (hiburan), menyelesaikan pekerjaan dan komunikasi efektif dalam menunjang keseharian hidup. Teknologi media informasi selalu tersambung dengan internet untuk menghubungkan dan memenuhi kebutuhan seorang individu ke dunia virtual (maya), misalnya Instagram, Facebook, Youtube, Academia.edu, Tokopedia, Traveloka, dan sebagainya. Hal ini memungkinkan seseorang mendapatkan informasi terbaru tingkat global secara instan dan kemudahan berkomunikasi tanpa batasan jarak.

Walidah (2017) berpendapat bahwa,

“Generasi millennial adalah istilah cohort dalam demografi, merupakan kata benda yang berarti pengikut atau kelompok. Saat ini ada empat cohort besar dalam demografi, yaitu Baby Boomer (lahir pada tahun 19461964), Gen-X (lahir pada tahun 1965-1980), Millennial (lahir pada tahun 1981-2000), dan Gen-Z (lahir pada tahun 2001-sekarang)".

Kebiasaan dalam dunia virtual menjadi lekat dengan gaya generasi millennial yang memang terlahir dan tumbuh di era teknologi kepintaran buatan (artificial intelligence). Generasi millennial lebih menyukai lingkungan kerja dengan budaya yang terbuka dan waktu yang fleksibel, di mana hal tersebut membuat perilaku penelusuran informasi bersifat instan.

Saat ini, peningkatan kebutuhan informasi pada masyarakat dipengaruhi kebutuhan informasi sebagai alat untuk memenuhi kepuasan diri, kesenjangan pengetahuan dengan permasalahan yang dihadapi. Era ini, generasi millennial harus mampu beradaptasi untuk terus bertahan hidup. Kemajuan teknologi di bidang komunikasi massa telah menunjang perilaku informasi "budaya global". Masyarakat secara sadar atau tidak telah melakukan transisi secara acculturation, yaitu proses pembentukan budaya baru melalui pertukaran budaya setelah adanya kontak antar budaya yang diambil dari bangsa lainnya dengan tanpa membuang unsur budaya asli. Kini, kita menghadapi dilema tergusurnya budaya asli karena kekuatan budaya global dari luar telah menimbulkan acculturation negative yang mengambil unsur buruk budaya lain.

Teknologi media massa

memberikan kebebasan berbicara yang memengaruhi budaya dalam berperilaku generasi millennial. Informasi diciptakan atau diproduksi individu maupun instansi melalui perantara media sosial (MEDSOS) sehingga informasi tersebut dapat memengaruhi pola berpikir, dan meninggalkan kesan bahkan menumbuhkan simpati seseorang dalam mengambil tindakan sebuah kelompok. Informasi yang bebas diakses menjadikan generasi millennial mengambil kesempatan dalam membuat dan menyebarkan konten digital yang provokatif, misalnya internet meme, false news, hate speech, hoax, dan sebagainya.

$$
\text { Sangat disayangkan apabila }
$$

informasi yang disampaikan tersebut adalah informasi yang sengaja atau dibuat salah terlebih merupakan sebuah kebohongan (hoax) dengan judul yang sangat provokatif mengiringi pembaca dan penerima opini yang negatif. Opini negatif, fitnah, hate speech beredar untuk 
menyerang seseorang atau kelompok tertentu dengan mengancam dan dapat merugikan pihak yang diberitakan sehingga dapat merusak reputasi. Selain itu, hal ini dapat juga melibatkan orangorang di sekitarnya agar tercekam karena rasa takut, menimbulkan kepanikan massal hingga kerugian materi akibat perusakan fasilitas umum. Terlebih lagi apabila informasi yang pada awalnya dibuat untuk tujuan baik menjadi sebuah manipulasi alat berita kebohongan (hoax), melalui judul yang sangat provokatif untuk menggiring pembaca dan penerima opini penuh kenegatifan.

Burange and Misalkar (2015) dalam Junaidi (2015) menyatakan bahwa, fenomena disinformasi di masyarakat disebabkan beberapa faktor. Pertama, pengaruh IoT sebagai sumber informasi generasi millennial.

"Internet of Things (IoT) adalah struktur objek yang menyediakan pemilik ke dalam identitas rahasia, dan kemampuan penyaluran data melalui jaringan tanpa bertatap muka dengan orang melainkan langsung ke sumber tujuan, yaitu interaksi manusia ke komputer jarak jauh dalam" (Junaidi, 2015).

Saat ini, IoT telah diterapkan di beberapa bidang, seperti bidang ilmu kesehatan, informatika, geografis dan lainlain. Infrastruktur internet yang semakin berkembang sehingga bukan hanya smartphone atau komputer saja yang dapat terkoneksi dengan internet. Namun, berbagai macam objek dapat terkoneksi melalui internet. Berbagai macam impelementasi IoT terjadi dalam kehidupan di era millennial ini, contohnya perkembangan sumber informasi adalah sistem penelusuran informasi, keamanan gedung (CCTV), peralatan elektronik otomatis, e-book/e-journal speech reader, dan seterusnya berbagai macam benda nyata yang tersambung ke jaringan lokal hingga global akan dikontrol menggunakan sensor atau sinyal data.

Kedua, faktor hate speech yang menimbulkan dampak di masyarakat. Febriyani, Sunarto and Husin (2018) berpendapat bahwa,

“Ujaran kebencian (hate speech) dapat didefinisikan sebagai ucapan dan/atau tulisan yang dibuat seseorang di muka umum untuk tujuan menyebarkan dan menyulut kebencian sebuah kelompok terhadap kelompok lain yang berbeda baik karena ras, agama, jenis kelamin, dan suku."

Hate speech adalah sebuah istilah yang berkaitan erat dengan pengaruh sebuah berita pada minoritas dan sekelompok masyarakat, yang menimpa orang tertentu untuk menjerumuskan orang tersebut ke dalam situasi penderitaan mental tanpa ada orang lain yang membantu atau yang peduli. Adapun bentuk dari hate speech antara lain, penghinaan, pencemaran nama baik penistaan, provokasi, penyebaran berita bohong, diskriminasi, konflik sosial, dan penghasutan.

Sarana atau alat yang mudah digunakan sebagai target pelaksanaan hate speech adalah media informasi dan komunikasi massa, di mana respons atau feedbacks pembaca dan sumber informasi berita sulit dilacak secara jelas kebenarannya. Bentuk hate speech yang dilakukan media massa cetak atau elektronik, yaitu: pertama, mudahnya pendistribusian dokumen atau pengaksesan informasi yang memiliki muatan pernyataan kebencian, penghinaan yang memprovokasi massa. 
Kedua, penyebaran berita bohong dan penyampaian pendapat ekstremis di muka umum untuk menimbulkan kerusuhan publik dengan menciptakan rasa kebencian dan permusuhan terhadap orang atau kelompok tertentu berdasarkan suku, agama, ras dan perbedaan golongan.

Fenomena disinformasi akibat perkembangan teknologi yang kontradiktif dan konspiratif ini membuktikan semakin sulitnya prediksi pola pikir dan nilai moral generasi modern. Perbedaan nilai kehidupan kelompok yang dapat menyeret semua golongan masyarakat tidak lagi terelakan hingga meningkat pada taraf permasalahan krisis sikap erosi nilai, erosi moral, erosi norma dan dehumanisasi dalam dunia tanpa batasan.

Maka, seseorang harus mampu memposisikan diri dalam ketahanan mental, disiplin diri yang adaptif, toleransi sosial, dan tatanan nilai dalam menghadapi dampak negatif yang dibawa kemajuan teknologi untuk menghindari krisis tersebut. Martini (2018) menyatakan, “Pembentukan karakter perlu dilakukan karena karakter akan berkaitan dengan moral seseorang yang ada pada diri setiap individu, dalam membangun karakter generasi muda yang tidak terlepas dari budaya yang ada di sekitarnya dan dalam hal ini harus adanya integrasi dari tiga lingkungan yakni keluarga, sekolah dan masyarakat." Pembentukkan karakter dapat dilakukan di tiga wilayah, yakni keluarga, sekolah, dan masyarakat. Hal ini melalui dukungan budaya yang dianut tiap individu di tempat tinggalnya sendiri. Generasi millennial dapat membangun karakter yang positif melalui peningkatan moral dalam memaknai hidup.
Adapun dalam praktik pendidikan, arah pelaksanaan disusun ke dalam suatu rancangan yang terorganisir, terstruktur, dan sistematis yang biasa disebut dengan kurikulum pembelajaran. Kurikulum pada umumnya memuat materi pendidikan dan proses pembelajaran sebuah pelaksanaan pendidikan. Materi pendidikan merupakan komponen dalam kurikulum yang berkaitan dengan bahan pada setiap mata pelajaran. Penentuan materi pendidikan dipengaruhi perumusan kebijakan nuansa (tema) pembelajaran pada setiap perubahan bentuk kurikulum, khususnya pada mata pelajaran Pendidikan Pancasila dan Kewarganegaraan (PPKN) yang terdapat penyimpangan informasi yang tidak dapat dihindari dengan alasan keamanan negara Indonesia.

Menurut Suastika and Sukadi (2017) menyebutkan bahwa unsur pendidikan budaya dan kewargaan di antaranya identitas nasional, kebangsaan dan kewarganegaraan, hak dan kewajiban warga negara, demokrasi dan masyarakat madani Indonesia, wawasan nusantara, dan hak azasi manusia. Pertama, identitas nasional merupakan pengetahuan dalam upaya penghayatan pancasila sebagai lambang pemersatu nasional dan pengembangan integrasi budaya negara yang multikultur.

Kedua, kebangsaan dan kewarganegaraan, merupakan pembelajaran akan hakikat bangsa Indonesia (Bhineka Tunggal Ika) dan kritis dalam upaya perwujudan pemersatu dalam konteks Negara Kesatuan Republik Indonesia (NKRI). Ketiga, hak dan kewajiban warga negara, merupakan pelaksanaan prinsip hubungan warga negara dan pemerintah negara dalam rangka penanaman nilai moral dan 
martabat yang bertanggungjawab kepada negara dan Tuhan Yang Mahaesa.

Keempat, demokrasi dan masyarakat madani Indonesia, merupakan penalaran mengenai konsep nilai yang bermakna terhadap perkembangan kehidupan sosial politik demokrasi dalam kehidupan bermasyarakat, berbangsa dan bernegara. Kelima, wawasan nusantara merupakan penghayatan nilai konsep sumber daya milik nusantara dalam kehidupan masyarakat, bangsa, dan negara. Keenam, hak azasi manusia (HAM) merupakan kemampuan menganalisis dalam mencari hakikat makna, pelanggaran dan pengadilan hingga perkembangan pemikiran hak asasi manusia di dunia maupun di Indonesia. Ketujuh, ketahanan nasional merupakan penghayatan dan menjunjung nilai perwujudan ketahanan negara dari ancaman luar maupun dalam.

Untuk memaksimalkan sebuah pembelajaran dalam pendidikan budaya dan kewargaan, competency literacy peserta didik dapat diintegrasikan secara bersamaan. Sebagai mana pengertian akan literates people yaitu seseorang yang berinformasi/terpelajar (literate) adalah mereka yang telah menyerap pengetahuan (pelajaran) dan mampu menggunakannya sesuai dengan kebutuhan (belajar). Mereka memahami hasil pembelajaran sehingga mengetahui bagaimana harus belajar yang tepat. Generasi millennial membentuk pemahaman atas pengorganisasian informasi menjadi pengetahuan, pemahaman cara pencarian informasi yang valid, dan penggunaan atau pemanfaatan informasi sehingga pengetahuan yang dihasilkan dapat memberikan pembelajaran kepada orang lain.
Orang yang terpelajar (literate) adalah individu yang telah siap untuk belajar sepanjang hayat. Mereka membentuk sikap literate dari kebiasaan sehari-hari, yaitu kebijaksanaan dalam pemanfaatan informasi dan kritis dalam pengambilan keputusan (Suwanto, 2015). Jika dikaitkan dengan pendidikan budaya dan kewargaan, orang yang terpelajar (literate) tentunya akan dengan mudah membiasakan diri menerapkan unsur dalam pembelajaran pendidikan budaya dan kewargaan.

Untuk menjadi generasi millennial yang cerdas dan terpelajar (literate), selain dibutuhkan pemahaman pendidikan budaya dan kewargaan, pendidikan karakter juga sangat penting untuk dibentuk. Pendidikan karakter dapat membentuk karakter yang baik dalam kehidupan melalui perilaku diri yang benar dalam membangun hubungan dengan orang lain, masyarakat, dan lingkungan.

Saleh (2016) menjelaskan bahwa,

"Penyelenggaraan pendidikan menjadi alat penanaman nilai karakter dan menjadi bagian dari upaya pemerintah dalam proses pembimbingan serta pembekalan bagi warga negara agar terbentuk kelompok dengan individu yang mandiri, bertanggung jawab, kreatif, berilmu, dan berakhlak mulia."

Pendidikan budaya dan karakter menjadi hal yang cukup penting yang berfungsi mengembangkan dan memperkuat potensi pribadi, juga untuk menyaring pengaruh dari luar yang akhirnya dapat membentuk karakter seseorang yang dapat mencerminkan budaya dari bangsa di Indonesia (Jaenudin, 2010). Pendidikan budaya penting diberikan pada generasi millennial 
agar mereka memiliki keahlian dalam menghadapi budaya luar.

Jaenudin (2010) pun kembali mengungkapkan bahwa, "Upaya pembentukan karakter sesuai dengan budaya bangsa tentu tidak semata-mata hanya dilakukan di sekolah namun melalui serangkaian kegiatan belajar mengajar baik melalui mata pelajaran maupun serangkaian kegiatan pengembangan diri yang dilakukan di kelas dan luar sekolah saja."

Pemimpin negara di seluruh dunia telah memperlihatkan dukungan terhadap kompetensi literasi penduduk di wilayahnya. Kemunculan program peningkatan literasi dalam segala bidang kehidupan yang dikhususkan pada pendidikan sejak dini bahkan pendidikan tambahan bagi orang dewasa. Pemerintah berkewajiban untuk memberantas permasalahan buta huruf (illiterate) penduduknya sebagai pemenuhan hak warga negara. Indonesia, sebagai salah satu bentuk kegiatan peningkatan literasi pada jenjang anak-anak dilakukan di sekolah yang dikenal melalui Program Gerakan Literasi Sekolah (GLS), sedangkan pada jenjang orang dewasa dilakukan secara massal, seperti program pendirian 1.000 perpustakaan desa atau taman baca masyarakat.

Yusup \& Saepudin menambahkan bahwa, "Literasi bukanlah sebuah karakteristik manusia sejak lahir, bukan juga unsur dasar kemampuan manusia, namun merupakan sebuah kemampuan yang dipelajari demi peningkatan kualitas hidup yang didapatkan dan digunakan dari di lingkungan sekolah maupun di luar sekolah." Bahkan dalam perkembangan terakhir, ada kecenderungan kemampuan literasi yang digunakan sebagai complementray skill pada kegiatan komunikasi sosial seseorang dengan kelompok di masyarakat dalam interaksi sosial, arus budaya modern, perkembangan bisnis, dan opini dalam politik.

Keahlian dalam literasi tidak hanya dapat menjadi kompetensi dalam satu konteks bidang kehidupan tetapi bersingungan sebagai multidimensi yang dapat memengaruhi berbagai bidang secara bersamaan. Pemahaman mengenai literasi juga dapat dilihat dari jenis kegunaannya yaitu literasi dasar dan literasi fungsional. Penguasaan literasi dalam segala aspek kehidupan memang menjadi hal yang penting untuk kemajuan peradaban suatu bangsa. Tidak mungkin menjadi bangsa yang besar, apabila hanya mengandalkan budaya oral yang mewarnai pembelajaran di lembaga sekolah maupun perguruan tinggi (Permatasari, 2015). Namun disinyalir bahwa tingkat literasi khususnya di kalangan sekolah semakin tidak diminati. Hal ini jangan sampai menunjukkan ketidakmampuan dalam mengelola sistem pendidikan yang mencerdaskan kehidupan bangsa. Maka, sudah saatnya budaya literasi harus lebih ditanamkan sejak usia dini agar anak bisa mengenal bahan bacaan dan menguasai dunia tulismenulis. Hal ini dilakukan juga sebagai langkah dalam pembentukan generasi millennial yang lebih cerdas dan terpelajar (literate) ke depannya.

Maka dapat dikatakan bahwa literasi adalah kemampuan teknis dari seseorang terhadap pemahaman keperluan atau penguasaan informasi dari pengamatan di lingkungan masyarakat yang menghasilkan pengetahuan yang bermanfaat dalam pengembangan diri. Selanjutnya sebuah pengetahuan dalam 
konteks tertentu dapat dipahami dengan beragam sudut pandang melalui jenis literasi yang berbeda, contohnya, seperti literasi dini yang merupakan kemampuan memahami informasi dari sumber dasar. Literasi informasi yang menggambarkan kemampuan teknis penggunaan informasi secara bijak oleh seseorang dalam masyarakat. Literasi teknologi yang merupakan kemampuan seseorang dalam penguasaan penggunaan peralatan teknologi digital. Literasi perpustakaan yang menggambarkan penguasaan seseorang dalam mencari dan memanfaatkan bahan pustaka di perpustakaan. Literasi media yang menggambarkan penguasaan terhadap penggunaan media publik untuk keperluan kerja dan sosialnya. Demikian pula dengan literasi budaya yang merupakan kemampuan pemahaman dalam adaptasi dan perkembangan budaya lokal yang berkembang dalam masyarakat Indonesia.

Literasi budaya dan kewargaan merupakan kemampuan yang harus dimiliki individu dan masyarakat untuk dapat bersikap di lingkungan sosial, sebagian bagian dari suatu budaya bangsa Indonesia. Kemampuan literasi budaya dan kewargaan harus dimiliki masyarakat terutama generasi millennial agar tetap mencintai serta dan bisa melestarikan kebudayaan lokal yang ada sebagai bagian dari identitas bangsa Indonesia. Selain itu, implementasi literasi budaya dan kewargaan juga dapat digunakan untuk mengatasi disinformasi yang terjadi di dalam kehidupan berbangsa ini terutama pada generasi millennial agar bisa mengolah informasi dengan lebih baik serta bisa tetap mencintai dan melestarikan budaya lokal (lokal konten) yang dimiliki Indonesia.
Implementasi literasi budaya dan kewargaan dalam mengatasi disinformasi pada generasi millennial dapat dilakukan melalui, pertama, pelaksanaan program kegiatan yang berisi tentang pengolahan informasi yang baik, dan kedua melalui penerapan literasi budaya dan kewargaan pada ranah sekolah, keluarga dan masyarakat. Adapun cara yang dapat dilakukan dalam penerapan literasi budaya dan kewargaan dalam mengatasi disinformasi pada generasi millennial di abad 21 ini, di antaranya pertama, penerapan tujuh pilar literasi informasi SCONUL, di antaranya "Identify, scope, manage dan present" (Cahyadi, 2018). Generasi millennial harus mampu mengidentifikasi kebutuhan informasi yang dibutuhkan. Lalu mereka dapat merumuskan pertanyaan mengenai informasi yang dibutuhkan atau mempersempit kajian. Terakhir, mereka dapat menggunakan informasi yang diperoleh sesuai etika dan legalitas.

Berdasarkan hal ini, seseorang akan diajarkan bagaimana cara mengolah informasi dengan baik dan menjadi seorang yang terpelajar (literate) terhadap informasi, yaitu mulai dari mengetahui kebutuhan akan informasi, mengolah, mengevaluasi, menggunakan sampai mengkomunikasikan informasi pada orang lain secara cerdas dan bijak. Kedua, penerapan literasi budaya dan kewargaan pada ranah sekolah, keluarga dan masyarakat.

Penerapan literasi budaya dan kewargaan di sekolah untuk mengatasi disinformasi pada generasi millennial dapat dilakukan melalui, pertama, pengadaan pelatihan tentang literasi budaya dan kewargaan serta bahaya disinformasi bagi generasi millennial untuk kepala sekolah, guru, tenaga 
kependidikan, pustakawan, tenaga kerja perpustakaan, agar mereka dapat mengimplementasikan literasi budaya dan kewargaan kepada siswa sekolah.

Kedua, pengadaan seminar pada siswa (SD, SMP, SMA) tentang literasi budaya dan kewargaan serta bahaya disinformasi di abad 21, agar siswa tidak melakukan disinformasi. Mereka dapat terhindar dari disinformasi serta bisa mencintai dan melestarikan budaya lokal (lokal konten) di Indonesia. Ketiga, penyediaan koleksi baik cetak maupun non cetak tentang budaya, kewargaan dan disinformasi di abad 21 ini. Keempat, harus ada kebijakan sekolah yang dapat mengembangkan literasi budaya dan nilai kewargaan di sekolah serta pencegahan dan cara untuk mengatasi disinformasi pada siswa. Kelima, dibentuknya komunitas anti disinformasi dan cinta budaya lokal.

Penerapan literasi budaya dan kewargaan di keluarga untuk mengatasi disinformasi pada generasi millennial dapat dilakukan melalui, pertama, penyedian bahan bacaan tentang budaya, kewargaan dan disinformasi dalam keluarga (di rumah), agar anak tertarik untuk membaca dan menerapkannya. Kedua, kegiatan wajib membaca bersama minimal 15 menit dalam keluarga setiap hari, agar anak terbiasa membaca.

Ketiga, penerapan literasi budaya dan kewargaan serta anti disinformasi kepada anak agar dapat mengetahui dari sejak dini. Keempat, mereka dapat berkunjung ke tempat yang mengandung nilai budaya seperti Candi Borobudur, Istana Maimunah, dan tempat lainnya yang memiliki nilai budaya. Kelima, memberikan pengajaran kepada anak tentang keberagaman di Indonesia, baik keberagaman suku bangsa, bahasa, kebiasaan, adat istiadat, kepercayaan, dan kebudayaan. Keenam, orang tua harus bisa menyediakan waktu luang untuk bisa berkumpul bersama anak, untuk mengetahui perkembangan anak dan apa yang dibutuhkan seorang anak di abad 21. Ketujuh, mengajarkan bahaya disinformasi pada anak agar anak bisa mengetahui bahaya dari disinformasi dan anti disinformasi.

Penerapan literasi budaya dan kewargaan di masyarakat dalam mengatasi disinformasi pada generasi millennial dapat dilakukan melalui pertama, penyedian bahan bacaan tentang budaya, kewargaan dan disinformasi di desa baik dalam bentuk perpustakaan maupun Taman Bacaan Masyarakat (TBM) agar masyarakat terutama generasi millennial tertarik membaca dan menerapkannya. Kedua, pengadaan pelatihan mengenai literasi budaya dan kewargaan serta bahaya disinformasi bagi generasi millennial untuk masyarakat, agar orang tua bisa mengimplementasikan literasi budaya dan kewargaan kepada anak agar terhindar dan bisa mengatasi bahaya dari disinformasi. Ketiga, pengadaan kegiatan studi budaya dari pemerintah daerah untuk masyarakat, yaitu seperti pengenalan budaya lokal, berkunjung ke tempat yang mengandung nilai budaya, dan sebagainya. Keempat, pengadaan kegiatan nasionalisme dan cinta terhadap keberagaman yang dimiliki Indonesia dari pemerintah daerah untuk masyarakat, contohnya seperti pengadaan peringatan hari-hari nasional, bela negara dan sebagainya agar masyarakat terutama generasi millennial tidak menjadi individualis, tetap mengutamakan kerja sama dan musyawarah bersama, dan bisa menjaga identitas bangsa Indonesia. Kelima, pengadaan kegiatan anti 
disinformasi dari pemerintah daerah kepada masyarakat, contohnya seminar anti disinformasi, bahaya disinformasi, dan cara mengatasi disinformasi untuk generasi millennial.

Penerapan literasi dalam membentuk perilaku atau kesadaran budaya dapat mencangkup seluruh lapisan/golongan di masyarakat. Proses implementasi pendidikan literasi budaya dan kewargaan, seperti yang telah dipaparkan di atas dibedakan atas jenis pelaksanaan pendidikan pengetahuan teoretis bagi setiap individu dan jenis pembentukan lingkungan penunjang kompentensi literasi tersebut dalam kehidupan sehari-hari. Penyelesaian permasalahan akibat disinformasi pada "budaya global" di era millennial dengan implementasi literasi budaya dan kewargaan akan membantu mempersiapkan nilai kepribadian dan kompetensi yang adaptif pada transisi acculturation positive terhadap budaya lokal penduduk NKRI. Pada akhirnya, implementasi literasi budaya dan kewargaan tidak hanya diutamakan bagi individu yang terlahir sebagai genarasi millennial hingga sekarang namun juga dapat mempersiapkan individu dari generasi sebelumnya.

\section{SIMPULAN}

Disinformasi

merupakan

penyampaian informasi yang secara disengaja bermaksud untuk membingungkan orang lain. Fenomena disinformasi ini banyak terjadi di masyarakat, terutama pada daerah yang tingkat melek informasinya masih kurang dan generasi yang paling rentan adalah generasi millennial. Permasalahan ini harus bisa diminimalisir dengan baik. Salah satu cara yang dapat dilakukan untuk mengatasi fenomena disinformasi ini diantaranya, pertama, pengolahan informasi dengan baik, dan kedua yaitu implementasi literasi budaya dan kewargaan pada ranah sekolah, keluarga dan masyarakat. Implementasi literasi budaya dan kewargaan sebagai solusi disinformasi pada generasi millennial ini dilakukan agar generasi millennial terhindar dari disinformasi dan bisa mengatasi fenomena tersebut dengan baik. Selain itu, generasi millennial agar tetap cinta dan dapat melestarikan kebudayaan sebagai identitas bangsa Indonesia. Penelitian studi literatur ini akan berpotensi untuk dikembangkan lagi pada penelitian selanjutnya, yakni meneliti konten budaya di website atau media sosial yang digunakan generasi millennial. Implementasi literasi budaya dan kewargaan sebagai solusi disinformasi pada generasi millennial sangat penting untuk dilakukan. Selain itu, hasil penelitian ini juga berpotensi sebagai bahan rujukan untuk penerapan literasi budaya dan kewargaan di sekolah, rumah dan masyarakat, dalam membentuk generasi millennial yang lebih literate (terpelajar), tetap mencintai dan bisa melestarikan sesuatu yang menjadi identitas bangsa ini.

\section{DAFTAR PUSTAKA}

Ahmad, A. (2013). Perkembangan media online dan fenomena disinformasi: Analisis pada sejumlah situs Islam. Jurnal Pekommas, 16(3), 177-186. https://doi.org/10.30818/jpkm.2013. 1160305

Cahyadi, D. A. (2018). Kemampuan literasi informasi peneliti dalam penulisan karya ilmiah di Loka Litbangkes Pangandaran. Kajian Informasi $\mathcal{E}$ Perpustakaan, 6(2), 139-150. 
https:// doi.org/10.24198/jkip.v6i2.17 774

Febriyani, M., Sunarto DM., \& Husin, B. R. (2018). Analisis faktor penyebab pelaku melakukan ujaran kebencian (hate speech) dalam media sosial. Jurnal POENALE, 6(3), 1-14. Retrieved from

http://jurnal.fh.unila.ac.id/index.ph p/pidana/article/view/1285/1122

Henriette, S. C., \& Windiani, R. (2018). Pemberdayaan literasi media dan informasi (LMI) UNESCO sebagai sarana pencegahan penyebaran hoaks. Jurnal Litbang Provinsi Jawa Tengah, 16(1), 59-66. Retrieved from http://ejournal.bappeda.jatengprov.g o.id/index.php/litbangjateng/article /view/747/616

Irianto, P. O., \&, \& Febrianti, L. Y. (2017). Pentingnya penguasaan literasi bagi generasi muda dalam menghadapi MEA. In Konferensi Internasional Pendidikan dan Bahasa 1: Pengembangan Bahasa Internasional di UNISSULA (pp. 640-647). Semarang: UNISSULA. Retrieved from http://jurnal.unissula.ac.id/index.ph p/ELIC/article/view/1282/989

Istiana, P. (2016). Gaya belajar dan perilaku digital native terhadap teknologi digital dan perpustakaan. In Prosiding Seminar Nasional: SLiMS Commeet West Java 2016 "Senayan Library Management System Community Meet Up West Java (pp. 343-350). Bandung: Unpad Press. Retrieved from

https://repository.ugm.ac.id/139214

/1/Proceeding Seminar SLiMS Commeet West Java 2016 1.pdf

Jaenudin, R. (2010). Peningkatan kualitas pendidikan melalui pendidikan budaya dan karakter bangsa. In
Seminar Nasional Pendidikan:

Pentingnya Membangun Karakter dan Jati Diri Peserta Didik dalam Mewujudkan Keberhasilan Proses Pembelajaran (pp. 1-16). Lahat: Universitas Sriwijaya. Retrieved from http://eprints.unsri.ac.id/3900/2/isi _makalah-17.pdf

Junaidi, A. (2015). Internet of things, sejarah, teknologi dan penerapannya: Review. Jurnal Ilmiah Teknologi Infromasi Terapan, 1(3), 62-66. Retrieved from http://jitter.widyatama.ac.id/index.p $\mathrm{hp} /$ jitter/article/view/51/35

Kementrian Pendidikan dan Kebudayaan. (2017). Materi pendukung literasi budaya dan kewargaan: Gerakan literasi nasional. Retrieved November 10, 2018, from http://gln.kemdikbud.go.id/glnsite/ wp-

content/uploads/2017/10/literasiBUDAYA-DAN-KEWARGAAN.pdf

Martini, E. (2018). Membangun karakter generasi muda melalui modal pembelajaran berbasis kecakapan abad 21. Jurnal Pancasila Dan Kewarganegaraan, 3(2), 21-27. https://doi.org/10.24269/jpk.v3.n2.2 018

Novianto, D. (2017). Optimasi waktu query dan filtering nama domain pada DNS server lokal menggunakan BIND 9. Jurnal Ilmiah Informatika GLOBAL, 8(2), 37-42. Retrieved from http://ejournal.uigm.ac.id/index.php /IG/article/view/320/363

Permatasari, A. (2015). Membangun kualitas bangsa dengan budaya literasi. In Prosiding Seminar Nasional Bulan Bahasa UNDIB 2015 (pp. 146156). Bengkulu: Universitas Bengkulu. Retrieved 
http://repository.unib.ac.id/11120/1 /15-Ane Permatasari.pdf

Putra, Y. S. (2016). Theoritical review: Teori perbedaan generasi. Jurnal Among Makarti, 9(18), 123-134. Retrieved from http://jurnal.stieama.ac.id/index.ph $\mathrm{p} / \mathrm{ama} /$ article/view/142/133

Saleh, S. (2016). Peran lembaga pendidikan dalam membentuk karakter bangsa. In Seminar Nasional: Pendidikan IlmuIlmu Sosial Membentuk Karakter Bangsa dalam Rangka Daya Saing Global (pp. 101-112). Makassar: Universitas Negeri Makassar. Retrieved from http://ojs.unm.ac.id/index.php/PSN -HSIS/article/download/2735/1474

Suastika, I. N., \& S. (2017). Pendidikan kewarganegaraan. Yogyakarta: Andi Offset.
Suwanto, S. A. (2015). Analisis literasi informasi pemakai taman bacaan masyarakat. Jurnal Kajian Informasi $\mathcal{E}$ Perpustakaan, 3(1), 89-100. https://doi.org/10.24198/jkip.v3i1.94 92

Walidah, I. A. (2017). Tabayyun di era generasi millennial. Jurnal Living Hadis, 2(2), 317-344. https://doi.org/10.14421/livinghadis .2017 .1359

Yusup, P. M., \& Saepudin, E. (2017). Praktik literasi informasi dalam proses pembelajaran sepanjang hayat. Kajian Informasi \& Perpustakaan, 5(1), 79-94.

https://doi.org/10.24198/jkip.v5i1.11 387 
